\title{
Research Article: Response of capsicum to different irrigation schedules under protected and open cultivation
}

\author{
Q RAJANEE SALUNKHE, S.B. WADATKAR, M.U. KALE, K.V.R. RAO AND \\ M.M. DESHMUKH
}

Article Chronicle:

SUMMARY : The experiment was conducted during late Rabi season (December to May) in year 2013Received :

11.07.2017;

14, at trial cum demonstration field of Precision Farming Development Centre, Central Institute of

Accepted :

26.07.2017

\section{KeY Words:}

Protected cultivation, Drip irrigation, Plastic Mulch,WUE, Crop yield Agricultural Engineering, Bhopal (M.P.) to check response of capsicum to different irrigation schedules under protected and open cultivation. The treatment comprising of three growing environments viz., naturally ventilated polyhouse, shadehouse and open field and three irrigation levels at $100 \% \mathrm{ETc}$, 80\% ETc and 60\% ETcin Factorial Randomized Block Design with nine treatment combinations and three replications. The study revealed that under polyhouse the crop yield was increased over open field cultivation along with water saving in covered cultivation.In case of vegetative character like plant height, number of leaves per plant and Spad value which depicts chlorophyll content in plant, reproductive parameters like number of flowers and fruits per plant, was maximum under naturally ventilated polyhouse followed by shadehouse and then open field at all growth stages. Days taken for flower initiation and fruit set were significantly lower in naturally ventilated polyhouse followed by shadehouse then open field.Higher yield with minimum crop water requirement gives maximum water use efficiency which is observed in treatment $\mathrm{T}_{9}$ (drip irrigation at 60\% ETc under polyhouse) i.e. 30.29 $\mathrm{q} / \mathrm{ha}-\mathrm{cm}$. However, minimum water use efficiency was noticed in treatment $\mathrm{T}_{4}$ (drip irrigation at $100 \%$ ETc under shadehouse) i.e. $12.25 \mathrm{q} / \mathrm{ha}-\mathrm{cm}$ although it having higher yield than open field but also it required maximum consumptive use. The significantly superior yield was recorded under the growing condition $\mathrm{C}_{3}$ i.e.polyhouse and irrigation level $\mathrm{I}_{3}$ i.e. drip irrigation at $60 \% \mathrm{ETc}$, whereas in treatment combination $\mathrm{I}_{3} \mathrm{C}_{3}$ (drip irrigation at $60 \%$ ETc under polyhouse) are found significantly superior yield (1163.7 q/ha) over rest combination.

How to cite this article : Salunkhe, Rajanee, Wadatkar, S.B., Kale, M.U., Rao, K.V.R. and Deshmukh, M.M. (2017). Response of capsicum to different irrigation schedules under protected and open cultivation. Agric.

Author for correspondence : Update, 12 (TECHSEAR-4): 995-1001; DOI: 10.15740/HAS/AU/12.TECHSEAR (4)2017/995-1001.

RAJANEE SALUNKHE Department of Irrigation and Drainage Engineering, Dr. Panjabrao Deshmukh Krishi Vidyapeeth, AKOLA (M.S.) INDIA Email:salunkhe7988@ gmail.com

See end of the article for authors' affiliations 